\title{
INVESTIGATION OF ANTIOXIDANT POTENTIAL OF QUERCETIN AND HESPERIDIN: AN IN VITRO APPROACH
}

\author{
SRIMATHI PRIYANGA K, VIJAYALAKSHMI K* \\ Department of Biochemistry, Bharathi Women's College, Chennai - 600 108, Tamil Nadu, India. Email: viji42research@yahoo.co.in.
}

Received: 25 July 2017, Revised and Accepted: 13 July 2017

ABSTRACT

Objective: The study was carried out to evaluate the antioxidant potential of quercetin and hesperidin.

Methods: The antioxidant potential of quercetin and hesperidin was estimated using free radicals in in vitro condition. Antioxidant activity of quercetin and hesperidin was estimated using 1,1-diphenyl-2-picrylhydrazyl (DPPH), superoxide, nitric oxide, hydroxyl radical, hydrogen peroxide radical, and reducing power assay.

Results: Quercetin and hesperidin have high efficiency in scavenging free radicals. Both the compounds are more efficient in scavenging DPPH (IC50 value $36.15 \pm 0.30$ and $41.55 \pm 0.49 \mathrm{mg} / \mathrm{ml}$ ) and superoxide radicals (IC 50 value $19.3 \pm 0.26$ and $28.08 \pm 0.18 \mathrm{mg} / \mathrm{ml}$ ) have high reducing capacity when compared to the standards ascorbic acid (IC50 value $31.45 \pm 1.31$ and $23.2 \pm 0.20 \mathrm{mg} / \mathrm{ml}$ ).

Conclusion: The present study suggests that quercetin and hesperidin have significant antioxidant activities and could be easily accessible to the immune system.

Keywords: Quercetin, Hesperidin, 1,1-diphenyl-2-picrylhydrazyl, Radical scavenging activity.

(C) 2017 The Authors. Published by Innovare Academic Sciences Pvt Ltd. This is an open access article under the CC BY license (http://creativecommons. org/licenses/by/4. 0/) DOI: http://dx.doi.org/10.22159/ajpcr.2017.v10i11.20260.

\section{INTRODUCTION}

In the living system, free radicals of different forms are frequently generated for specific metabolic requirements. When the generation of these species exceeds the levels of antioxidant mechanism, they cause wide-ranging damage to the cells leading to oxidative damage that in saw in the disease conditions, especially degenerative diseases. The endogenous antioxidants act as intracellular protection systems protecting the cells from free radical damage and extensive lysis. Scavenging and retreating the formation of oxygen-derived species if not $100 \%$ efficient. Different disease conditions are associated with free radical oxidative stress. Herbal drugs containing free radicals scavengers such as phenolics, tannins, flavonoids and flavanones are renonowned for their therapeutic acitivity [1]. There are thousands of medicines and natural products that have been closely linked through the use of traditional medicines. Organic products represent a wealthy source of biologically active compounds with conventional potential for drug discovery and development [2]. In flowers also have a free radical activity such as Jasminum grandiflorum (L.) flower [3]. The best described property of quercetin is its ability to act as an antioxidant. It appears to be the most powerful flavonoid for protecting the body against reactive oxygen species (ROS), produced during the normal $\mathrm{O}_{2}$ metabolism or induced by exogenous damage [4]. These include enzymatic and non-enzymatic antioxidants that remain in check the ROS level and repair the oxidative cellular damage. The major enzymes, constituting the first line of defense, directly involved in the neutralization of ROS are superoxide dismutase, catalase and glutathione peroxidase. Repair and de novo enzymes act as the third line of defense by repairing damage and reconstituting membranes which include lipases, proteases, DNA repair enzymes and transferases [5]. Quercetin acting as a free radical scavenger was shown to exert a protective effect in reperfusion in ischemic tissue damage [6] by various ways. It prevents free radical induced tissue injury. One way is the direct scavenging of free radicals, by scavenging free radicals, flavonoids particularly can inhibit low-density lipoprotein oxidation in vitro [7]. Quercetin leads to a reduction in ischemia-reperfusion injury by interfering with inducible nitric oxide (NO) synthesis activity [8]. It causes scavenging of free radicals, and therefore can no longer reacts with NO, ensuing less damage [9]. Free radicals are very stable and react speedily with other compounds, trying to capture the needed electron to gain stability. Generally free radicals attack the nearest stable molecules, "stealing" its electron. When the attack molecules lose its electron it becomes a free radical itself, beginning a chain reaction. Once the process is started, it can cascade finally resulting in the disruption of living cells. Some free radicals arise normally during metabolism. However, environmental factors such as pollution, radiation, cigarette smoke and herbicides can also spawn free radicals. ROS include hydroxyl radicals $(\mathrm{OH})$, superoxide anion $\left(\mathrm{O}_{2}\right)$, hydrogen peroxide $\left(\mathrm{H}_{2} \mathrm{O}_{2}\right)$, NO, peroxynitrite and nitrosyl with the $\mathrm{OH}$ being the most harmful. Quercetin is one of the most frequently studied bioflavonoid in its class of flavonol. It has been shown to have cytoprotective effects in preventing endothelial apoptosis caused by oxidants [10]. Quercetin is a more potent antioxidant than other antioxidant nutrients, such as vitamin $C$, vitamin $E$, and $\beta$-carotene, and it can chelate transition metal ions, including iron, thus preventing the iron-catalysed Fenton reaction $[11,12]$. Hesperidin is a naturally occurring flavanone that exists in citrus and other plants [13]. Hesperidin is reported to exert a wide range of pharmacological effects [14]. It has been demonstrated that hesperidin can protect neurons against various types of insults associated with many neurodegenerative diseases [15]. Hence, it was planned to investigate on the antioxidant potential of quercetin and hesperidin.

\section{METHODS}

Ascorbic acid, nicotinamide adenine dinucletide (NADH), nitro blue tetrazolium (NBT), phenazine methosuphate (PMS), EDTA, sulphanilamide, N-(1-naphthyl) ethylene diamine dihydrochloride were purchased from Hi-Media-Ltd., Mumbai, India. 1,1-diphenyl-2picrylhydrazyl (DPPH), quercetin and hesperidin were purchased from Sigma Chemical co., St. Loius, MO, USA. All other chemicals used were of analytical grade (Sigma Aldrich). 


\section{DPPH}

The antioxidant activities of quercetin and hesperidin was determined in term of hydrogen donating or radical scavenging ability using the stable radical DPPH carried out by using the method of Mensor et al. [16]. About $0.3 \mathrm{mM}$ solution of DPPH in $100 \%$ ethanol was prepared and $1 \mathrm{ml}$ of this solution was added to $3 \mathrm{ml}$ of the sample dissolved in ethanol at different concentration $(10-50 \mu \mathrm{g} / \mathrm{ml})$. The mixture was added and incubated in dark for 30 minutes and $1 \mathrm{ml}$ of ethanol served as control. The change in color was observed in terms of absorbance using a spectrophotometer at $517 \mathrm{~nm}$. Ascorbic acid was invoked as standard. Radical scavenging activity was expressed as the inhibition percentage of free radical by the sample and was calculated using the formula:

$(\%)=\left[\left(\mathrm{Ac}-\mathrm{A}_{\mathrm{T}} / \mathrm{A}_{\mathrm{C}}\right] \times 100\right.$

\section{Superoxide radical (SO) scavenging activity}

The SO scavenging activity was studied by using the method of Liu et al. [17] SOs are generated in PMS-NADH systems by oxidation of NADH and assayed by the reduction of NBT. Different concentration $(10-50 \mu \mathrm{g} / \mathrm{ml})$ of the sample solution was taken in a series of test tubes. SO were generated by $1 \mathrm{ml}$ of Tris-HCL buffer (16 mM, pH - 8), $1 \mathrm{ml}$ of NBT $(50 \mu \mathrm{M}), 1 \mathrm{ml}$ of NADH $(78 \mu \mathrm{M})$ solution and $1 \mathrm{ml}$ of PMS $(10 \mu \mathrm{M})$. The reaction mixture was incubated at $25^{\circ} \mathrm{C}$ for 5 minutes and the absorbance was measured at $560 \mathrm{~nm}$ in spectrophotometer. The IC50 values of quercetin and hesperidin were calculated and compared with ascorbic acid (standard) solution. The percentage inhibition of $\mathrm{O}_{2}$ generation was calculated as follows:

$\%$ Inhibition $=[(\mathrm{Ac}-\mathrm{At}) / \mathrm{Ac}] \times 100$

\section{NO radical scavenging activity}

NO radical - scavenging activity was measured spectrophotometrically depending to the method described by Govindarajan et al. [18]. When sodium nitroprusside was mixed with an aqueous solution at physiological $\mathrm{pH}$, it generated $\mathrm{NO}$, which reacts with oxygen to produce nitrite ions that can be estimated using the Greiss reagent. To $2 \mathrm{ml}$ of sodium nitroprusside $(5 \mathrm{mM}), 0.5 \mathrm{ml}$ of phosphate buffer ( $\mathrm{pH}$ - 7.4) was mixed with different concentrations of the quercetin and hesperidin $(10-50 \mu \mathrm{g} / \mathrm{ml})$. The tubes were then incubated at $25^{\circ} \mathrm{C}$ for $2.5 \mathrm{hrs}$. After incubation $0.5 \mathrm{ml}$ of the reaction mixture, $1.0 \mathrm{ml}$ of sulphanilic acid was added and incubated at room temperature for 5 minutes for complete diazotization. Finally, $1.0 \mathrm{ml}$ of $5 \% \mathrm{~N}$-napthyl ethylene diamine dihydrochloride was added, mixed and incubated at room temperature for 5 minutes to form pink coloured chromphore. The absorbance was then measured at $546 \mathrm{~nm}$ against the equivalent blank solution, decreased absorbance of the reaction mixture indicated increased scavenging activity. The IC50 value of the test solution was calculated and compared with that of ascorbic acid.

\section{Hydroxyl radical scavenging assay}

Hydroxyl radicals $(\mathrm{OH})$ are generated from $\mathrm{Fe} 2+-\mathrm{EDTA}-\mathrm{H}_{2} \mathrm{O}_{2}$ system (Fenton's reaction) The hydroxyl radical-scavenging activity of quercetin and hesperidin was measured according to the method of Halliwell et al. [19] stock solutions of EDTA (0.1 mM) were prepared in dimethyl sulfoxide and $\mathrm{FeCl}_{3}(0.1 \mathrm{mM})$, ascorbic acid $\left.(0.1 \mathrm{mM}), \mathrm{H}_{2} \mathrm{O}_{2} 4 \mathrm{mM}\right)$ and deoxyribose $(2.8 \mathrm{mM})$ were prepared in distilled water. The method was carried out by adding $100 \mu \mathrm{l}$ of EDTA, $10 \mu \mathrm{l}$ of $\mathrm{FeCl}_{3}, 100 \mu \mathrm{l}$ of $\mathrm{H}_{2} \mathrm{O}_{2}$, $360 \mu \mathrm{l}$ of deoxyribose, and different concentrations $(10-50 \mu \mathrm{g} / \mathrm{ml})$ of compounds was dissolved in distilled water, $330 \mu \mathrm{l}$ of phosphate buffer ( $50 \mathrm{mM}, \mathrm{pH} 7.4)$ and $0.1 \mathrm{ml}$ of ascorbic acid. This mixture was then incubated at $37^{\circ} \mathrm{C}$ for 10 minutes. $1 \mathrm{ml}$ of the incubated mixture was mixed with $1 \mathrm{ml}$ of $10 \%$ trichloroacetic acid and $1 \mathrm{ml}$ of $0.5 \%$ thio barbituric acid was added and the tubes were boiled for 30 minutes. After incubation, colour was developed and measured at $532 \mathrm{~nm}$ in spectrophotometer. The IC50 values of the test sample were calculated and compared with ascorbic acid (standard). The values are expressed as percentage of inhibition.

\section{$\mathrm{H}_{2} \mathrm{O}_{2}$ scavenging activity}

Scavenging of $\mathrm{H}_{2} \mathrm{O}_{2}$ was determined by the method of Ruch et al. [20]. The procedure was started with different concentrations $(10-50 \mu \mathrm{g} / \mathrm{ml})$ of test solution, $500 \mu \mathrm{l}$ of buffer and $400 \mu \mathrm{l}$ of $2 \mathrm{mM} \mathrm{H}_{2} \mathrm{O}_{2}$ were added. The mixture was kept at the room temperature for 5 minutes. After incubation $2 \mathrm{ml}$ of dichromate acetic acid reagent was added and colour intensity was measured at $570 \mathrm{~nm}$. The blank solution contains $2 \mathrm{ml}$ of dichromate acetic acid alone. Whereas the reaction mixture without compound served as control. The percentage of inhibition was calculated and compared with Ascorbic acid as the standard.

\section{Reducing power assay}

The reducing power was determined according to the method of Oyaizu [21]. The different concentrations of test solution $(10-50 \mu \mathrm{g} / \mathrm{ml})$ were added to $0.1 \mathrm{ml}$ of DTC reagent contain $(0.4 \mathrm{~g}$ of thiourea, $0.05 \mathrm{~g}$ of copper sulphate and $3 \mathrm{~g}$ of DNPH) and incubated at $37^{\circ} \mathrm{C}$ for $3 \mathrm{hrs}$. To the mixture $0.75 \mathrm{ml}$ of $85 \% \mathrm{HCl}$ was added and incubated at room temperature for 30 minutes. Ascorbic acid served as control. Intensity of colour developed was read at $520 \mathrm{~nm}$ using a spectrophotometer. The reducing power was calculated and compared with ascorbic acid.

\section{RESULTS}

The compound such as quercetin and hesperidin was investigated for the effects on the in vitro generation of free radicals. The results of the study showed that these two compounds could inhibit the free radicals such DPPH, SOs, NO, hydroxyl radicals and $\mathrm{H}_{2} \mathrm{O}_{2}$.

\section{DPPH}

DPPH free radical compound has been widely used to test the free radicals scavenging ability of various food samples. The antioxidant present neutralizes the DPPH by the transfer of an electron or hydrogen atom. The reduction capacity of DPPH could be determined by colour changes from purple to yellow by reading at $517 \mathrm{~nm}$. The DPPH radicalscavenging activity of quercetin and hesperidin was detected and compared with standard antioxidant-ascorbic acid. Both compounds tested revealed that they possessed excellent antioxidant capacity and it was dose dependent. The scavenging activity of ascorbic acid was high. The IC50 values of quercetin $(36.15 \mu \mathrm{g} / \mathrm{ml})$ and hesperidin was $41.55 \mu \mathrm{g} / \mathrm{ml}$ (Fig. 1).

\section{So scavenging assay}

The result of SO scavenging activity showed that both compounds could efficiently scavenge and it was dose dependent. In the present study, quercetin and hesperidin were found to be a notable scavenger of SOs generated in the reduced NBT. The IC50 values of quercetin was $19.3 \mu \mathrm{g} / \mathrm{ml}$ and hesperidin $28.08 \mu \mathrm{g} / \mathrm{ml}$ when compared with the ascorbic acid (23.2 $\mu \mathrm{g} / \mathrm{ml})$ (Fig. 2).

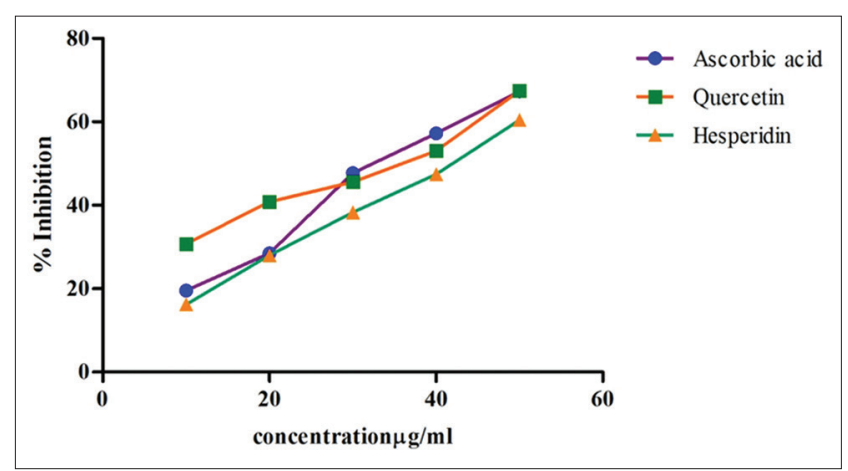

Fig. 1: The scavenging activity of quercetin and hesperidin as determined by on 1,1-diphenyl-2-picrylhydrazyl radical scavenging assay. Values are expressed in mean \pm standard deviation $(n=6)$ 
Nitric oxide radicals scavenging assay

Compound such as quercetin and hesperidin effectively reduced the generation of NO from sodium nitroprusside. IC50 value of quercetin and hesperidin at the concentration of $49.35 \mu \mathrm{g} / \mathrm{ml}$ and $45.11 \mu \mathrm{g} / \mathrm{ml}$ while the standard ascorbic acid was $35.56 \mu \mathrm{g} / \mathrm{ml}$. Scavenging of NO radical is based on the generation of NO from sodium nitroprusside in buffered saline, which reacts with oxygen to produce nitrite ions that can be measured by using Griess reagent. The absorbance of the chromophore was measured at $546 \mathrm{~nm}$ in the presence of the test solution proved the decreased amount of nitrite generated by the decomposition of sodium nitroprusside in vitro (Fig. 3).

\section{Hydroxyl radical scavenging assay}

In the present study, the hydroxyl radical-scavenging effect of the test compounds at different concentrations was studied with ascorbic acid was standard. It is found to be significantly effective in inhibition of hydroxyl radicals (Fig. 4). The IC50 value of quercetin, hesperidin and ascorbic acid was $31.4 \mu \mathrm{g} / \mathrm{ml}$ and $37.36 \mu \mathrm{g} / \mathrm{ml}$ and $27.01 \mu \mathrm{g} / \mathrm{ml}$ respectively.

\section{Scavenging of $\mathrm{H}_{2} \mathrm{O}_{2}$}

Scavenging of $\mathrm{H}_{2} \mathrm{O}_{2}$ by two compounds namely of quercetin and hesperidin is presented (Fig. 5). The percentage of $\mathrm{H}_{2} \mathrm{O}_{2}$ scavenging activity of quercetin and hesperidin was found to be $38.35 \mu \mathrm{g} / \mathrm{ml}$ and $46.1 \mu \mathrm{g} / \mathrm{ml}$ which is compared to antioxidant activity of standard ascorbic acid (11.15 $\mu \mathrm{g} / \mathrm{ml})$.

\section{Reducing power assay}

In the present study the reducing power of the compounds was found to be excellent and steadily increased in direct proportion to the increasing concentration of the compounds (Fig. 6). Which was relatively more pronounced than that of standard ascorbic acid. The reducing power of quercetin and hesperidin was found to be $50.06 \mu \mathrm{g} / \mathrm{ml}$ and $47.46 \mu \mathrm{g} / \mathrm{ml}$ while the standard antioxidant ascorbic acid was of $35.35 \mu \mathrm{g} / \mathrm{ml}$

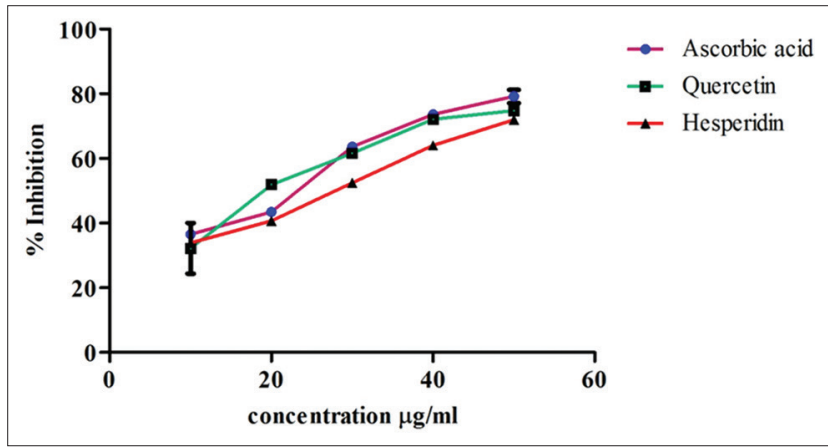

Fig. 2: The superoxide radical-scavenging activity of Quercetin and Hesperidin as determined. Values are expressed in mean \pm standard deviation $(n=6)$. Nitric oxide radicals scavenging assay

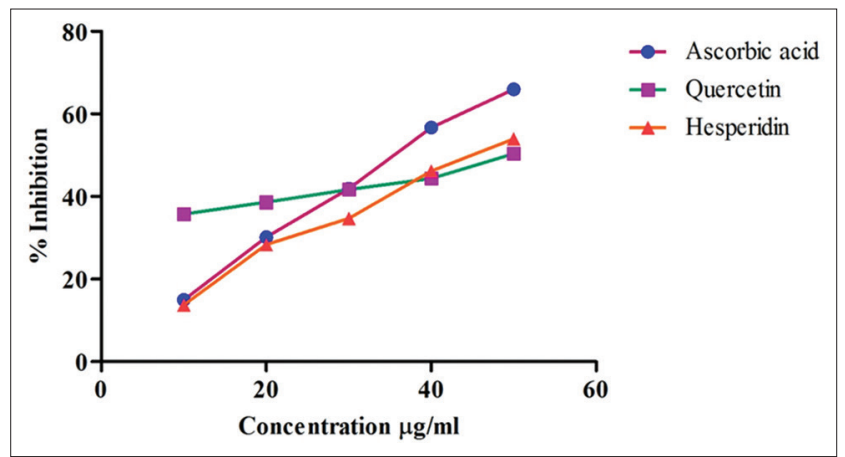

Fig. 3: Nitric oxide scavenging activity of quercetin and hesperidin as determined. Values are expressed in mean \pm standard deviation $(n=6)$

\section{DISCUSSION}

Stratil et al. [22] reported that DPPH is relatively stable and hence it is a less reactive free radicals, so it can be reduced primarily by more reactive reducing components such as phenolic substance. Kalaivani et al. [23] say that the DPPH is a free radical which has been widely accepted as a tool for estimating free radicals scavenging activities of antioxidants. SOs is known to be a very harmful species to cellular compounds as a precursor of more reactive species is reported by Halliwell and Gutteridge [24]. Esmaeili and Sonboli [25] suggested the $\mathrm{H}_{2} \mathrm{O}_{2}$ itself is not very reactive, but some times it is toxic to cell. So removing of $\mathrm{H}_{2} \mathrm{O}_{2}$ is very important for antioxidant defence in cell system. Polyphenols have also protect mammalian cells from damage induced by $\mathrm{H}_{2} \mathrm{O}_{2}$, especially compounds with the orthohydroxyphenolic compounds like quercetin, gallic acid, ceiffecic acid and catechin. Hofseth et al. [26] reports NO formed during their reduction with oxygen or with superoxide. These radicals are responsible for altering the structure and functional

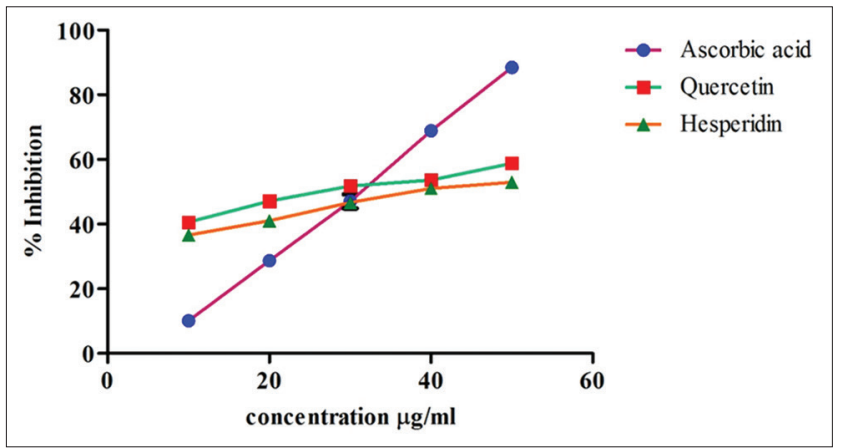

Fig. 4: Sacavenging activity of quercetin and hesperidin as determined by hydroxyl radical scavenging assay. Values are expressed by mean \pm standard deviation $(n=6)$

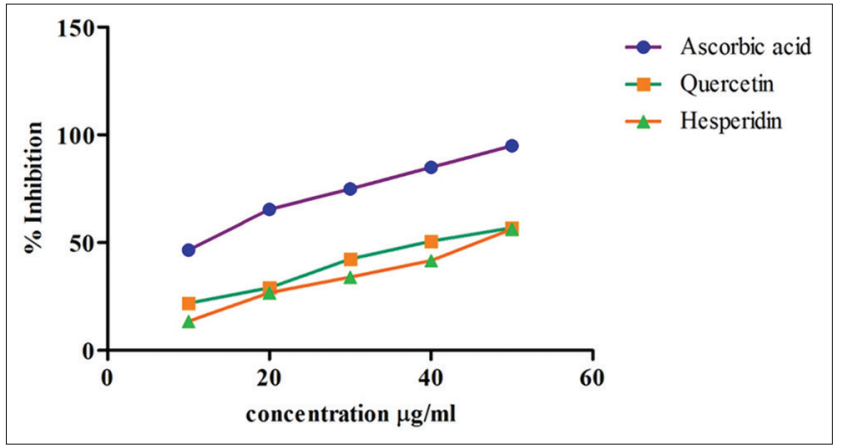

Fig. 5: The scavenging activity of quercetin and hesperidin as determined by $\mathbf{H 2 0 2}$. Values are expressed in mean \pm standard deviation $(n=6)$

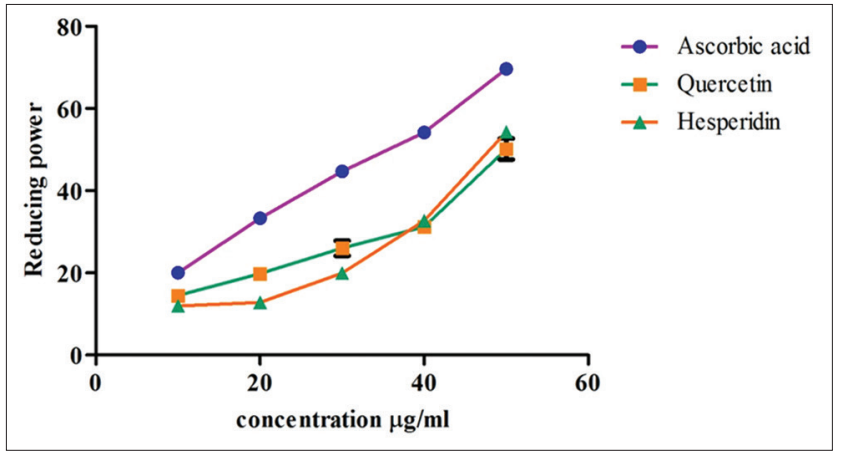

Fig. 6: The reducing power assay of quercetin and hesperidin Values are expressed by mean \pm standard deviation $(n=6)$ 
behavior of many cellular compounds. NO is also implicated for inflammation, cancer and other pathological conditions. Sulaiman et al. [27] say that the antioxidant activity of phenolic compounds is based on their ability to donate hydrogen atom to free radicals. In addition they posssess ideal structural activities. Mahadevan et al., reported that Mimosa pudica exerts have a neuroprotective effects [28]. This study reported that selenium enriched mushrooms also have prevention effect against neurodegenerative diseases [29] in treating oxidative stress related diseases.

\section{CONCLUSION}

The results obtained from the study suggest that both the compounds quercetin and hesperidin have significant antioxidant activities. Hence they could be helpful for the immune system against oxidative stress and its related disorder such as neurodegenerative diseases.

\section{REFERENCES}

1. Halliwell B. Free radicals and antioxidants: A personal view. Nutr Rev 1994;52:253-65.

2. Newman DJ, Cragg GM, Snader KM. Natural products as sources of new drugs over the period 1981-2002. J Nat Prod 2003;66(7):1022-37.

3. Chandran RP, Kalaiselvi M, Bhuvaneshwari V, Amsaveni R, Ragavendran P. In vitro assessment of free radical scavenging activity of Jasminum grandflorum (L) flower. Asian J Pharm Clin Res 2016;9(1):171-4

4. Grace PA. Ischemia-reperfusion-injuring. Br J Surg 1994;81:637-47.

5. Bahorun T, Soobrattee MA, Luximon-Rammav V. Free radicals and antioxidants in cardiovascular health and disease. Internet J Med Update 2006;1(2). Available from: http://www.geocities.com/agnihotrimed/ Paper 05 jul-dec 2006.htm.

6. Santos $\overrightarrow{A C}$, Uyemura SA, Lopes JL, Bazon JN, Mingatto FE, Curti C. Effect of naturally occurring flavonoids on lipid peroxidation and membrane permeability transition in mitochondria. Free Radic Biol Med 1998;24(9):1455-61.

7. Kerry NL, Abbey M. Red wine and fractionated phenolic compounds prepared from red wine inhibits low density lipoprotein oxidation in vitro. Atherosclerosis 1997;135:93-102.

8. Shoskes DA. Effect of bioflavonoids quercetin and curcumin on ischemic renal injury: A new class of renoprotective agents. Transplantation 1998;66(2):147-52.

9. Shutenko Z, Henry Y, Pinard E, Seylaz J, Potier P, Berthet F, et al. Influence of the antioxidant quercetin in vivo on the level of nitric oxide determined by electron paramagnetic resonance in rat brain during global ischemia and reperfusion. Biochem Pharmacol 1999;57(2):199-208.

10. Choi YJ, Kang JS, Park JH. Polyphenolic flavonoids differ in their antiapoptotic. Newman DJ, Cragg GM, Snader KM. Natural products as sources of new drugs over the period 1981-2002. J Nat Prod 2003; 66:1022-37

11. Rice-Evans CA, Miller NJ, Bolwell PG, Bramley PM, Pridham JB. The relative antioxidant activities of plant-derived polyphenolic flavonoids. Free Radic Res 1995;22(4):375-83
12. Ferrali M, Signorini C, Ciccoli L, Bambagioni S, Rossi V, Pompella A, et al. Protection of erythrocytes against oxidative damage and autologous immunoglobulin $\mathrm{G}$ ( $\mathrm{IgG}$ ) binding by iron chelator fluor-benzoilpyridoxal hydrazone. Biochem Pharmacol 2000;59(11):1365-73.

13. Crozier A, Jaganath IB, Clifford MN. Dietary phenolics chemistry, bioavailability and effects on health. Nat Prod Rep 2009;26(8):1001-43.

14. Chen MC, Ye YY, Ji G, Liu JW. Hesperidin upregulates heme oxygenase-1 to attenuate hydrogen peroxide-induced cell damage in hepatic L02 cells. J Agric Food Chem 2010;58(6):3330-5.

15. Cho J. Antioxidant and neuroprotective effects of hesperidin and its aglycone hesperetin. Arch Pharm Res 2006;29(5):699-706.

16. Mensor LL, Menezes FS, Leitace GG, Reis AS, Dos Santos TC, Coube CS, et al. Screening of Braziliam plant extracts for antioxidant activity by the use of DPPH free radical method. Phytother 2001; 15:127-30

17. Liu F, Ooi VE, Chang ST. Free radical scavenging activities of mushroom polysaccharide extracts. Life Sci 1997;60(10):763-71.

18. Govindarajan R, Rastogi S, Vijayakumar M, Shirwaikar A, Rawat AK, Mehrotra S, et al. Studies on the antioxidant activities of Desmodium gangeticum. Biol Pharm Bull 2003;26(10):1424-7.

19. Halliwell B, Gutteridge JM, Aruoma OI. The deoxyribose method: A simple 'test-tube' assay for determination of rate constants for reactions of hydroxyl radicals. Anal Biochem 1987;165(1):215-9.

20. Ruch R, Cheng S, Klanning J. Prevention of cytotoxicity and inhibition of inter cellular communication antioxidant catechins isolated from Chinese green tea. Carcinogenesis 1989;10:1003-8.

21. Oyaizu M. Studies on product of browning reaction prepared from glucose amine. Jpn J Nutr 1986;44:307-15.

22. Stratil P, Klejdus B, Kubán V. Determination of phenolic compounds and their antioxidant activity in fruits and cereals. Talanta 2007;71(4):1741-51.

23. Kalaivani T, Mathew L. Free radical scavenging activity from leaves of Acacia nilotica (L.) Wild. Ex Delile, an Indian medicinal tree. Food Chem Toxicol 2010;48(1):298-305.

24. Halliwell B, Gutteridge JM. Free Radicals in Biology and Medicine. $4^{\text {th }}$ ed. Oxford: Oxiford University Press; 2007.

25. Esmaeili MA, Sonboli A. Antioxidant, free radical scavenging activities of Salvia brachyantha and its protective effect against oxidative cardiac cell injury. Food Chem Toxicol 2010;48(3):846-53.

26. Hofseth LJ. Nitric oxide as a target of complementary and alternative medicines to prevent and treat inflammation and cancer. Cancer Lett 2008;268(1):10-30.

27. Sulaiman SF, Yusoff NA, Eldeeri IM, Seow EM, Sajak AA, Supriatno OK. Correlation between total phenolic and mineral contents with antioxidant activity of eight Malaysian bananas (Musa. sp). J Food Compos Anal 2011;24:1-10.

28. Mahadevan MU, Ramaswamy RS, Banumathi V. Mimosa pudica exerts neuroprotection against MPP+ induced neurotoxicity SHSY5Y cell lines-an in vitro model of anti-parkinsonism. Int $\mathrm{J}$ Pharm Pharm Sci 2017;9(1):21-6.

29. Rex DA. Selenium enriched mushrooms as a food supplement for prevention of neurodegenerative diseases. Int J Pharm Pharm Sci 2014;10(6):1-2. 